

\title{
Kontribusi Industri Tekstil dalam Penggunaan \\ Bahan Berbahaya dan Beracun Terhadap \\ Rusaknya Sungai Citarum
}

\author{
Oleh : Desriko Malayu Putra
}

\begin{abstract}
Abstrak
Indonesia merupakan Negara yang masuk dalam jajaran 10 besar pengekspor pakaian terbesar dunia dan pada tahun 2011 Indonesia merupakan negara pengekspor terbesar ke-11 di dunia. Indonesia adalah negara dengan ekonomi yang paling besar di Asia Tenggara, dan sektor tekstil menyumbang 8,9 persen total ekspor Indonesia pada 2010. Tulisan ini akan melihat bagaimana kontribusi sektor industri tekstil terhadap rusaknya Sungai Citarum. Metodologi penulisan ini munggunakan pendekatan yuridis normatif yang diperkuat oleh kasus kegiatan industri yang letaknya bersebelahan dengan Sungai Citarum. Sungai Citarum memiliki reputasi buruk sebagai sungai terkotor di dunia. Masalah kasat mata berupa sampah dan limbah domestik memang terlihat parah. Tetapi limbah dari bahan berbahaya dan beracun yang digunakan dalam industri tekstil merupakan sumber besar dari pencemaran dengan konsekuensi jangka panjang yang lebih serius, terutama di bagian hulu Sungai Citarum di mana terdapat 68 persen pabrik tekstil.
\end{abstract}

Kata kunci : sungai citarum, pencemaran, industri tekstil

1 Penulis adalah aktivis lingkungan, pernah berafiliasi sebagai pengkampanye di Greenpeace Indonesia dan Deputi Direktur WALHI Sumatera Barat. 


\begin{abstract}
Indonesia is a country that is included in the top 10 of the world's largest apparel exporter and in 2011 Indonesia was the 11th biggest exporter in the world. Indonesia is the country with the biggest economy in Southeast Asia, and the textile sector accounted for 8.9 percent of Indonesia's total exports in 2010. This article will look at how the textile industry contributes to the destruction of the Citarum River. This paper will usenormative juridical approach is reinforced by theindustry case located near Citarum River. The Citarum River has bad reputation as the dirtiest river in the world. Visible problem of garbage and domestic waste can be dismal. But hazardous waste and toxic use in the textile industry is also a major source of pollution, especially in the upper Citarum where 68 percent of the industry establishment are textile factories.
\end{abstract}

Keywords : citarum river, polluting, textile industries

\title{
I. Pendahuluan
}

Indonesia merupakan Negara yang masuk dalam jajaran 10 besar pengekspor pakaian terbesar dunia yang pada tahun 2011 merupakan negara pengekspor garmen terbesar ke-11 di dunia. Indonesia adalah negara dengan ekonomi yang paling besar di Asia Tenggara, dan sektor tekstil menyumbang 8,9 persen dari total ekspor negara ini pada $2010 .^{2}$ Tak bisa dipungkiri, perkembangan industri tekstil di Indonesia sedang "naik daun" seiring dengan kemajuan gaya berpakaian (fashion style) masyarakat. Lihat saja bagaimana desain baru pakaian berganti cepat, baik dalam bentuk motif yang sangat beragam maupun gaya yang disajikan yang menarik dan mencolok dan menjadi daya tarik tersendiri bagi kebutuhan gaya generasi muda saat ini.

Di Indonesia, khususnya di provinsi Jawa Barat yang merupakan pusat tekstil modern dan industri busana, banyak pabrik manufaktur beroperasi, misalnya di kawasan Bandung. Keberadaan industri tekstil di daerah ini telah berkontribusi pada pencemaran Sungai Citarum. Meski persoalan air limbah domestik yang tidak dikelola dan sampah secara kasatmata terlihat parah, namun limbah industri

2 Business Vibes; Industry Insight (2013). Tekstile Industry in Indonesia, http://www. busiinessvibes.com/blog/industry-insight-textile-industry-indonesia, export in term of monetary value. 
juga merupakan penyebab penting terhadap pencemaran sungai. Secara kuantitas limbah industri diklaim lebih sedikit dibandingkan limbah domestik, tetapi berdasarkan kajian air limbah industri lebih terkonsentrasi dan mengandung banyak materi-materi berbahaya. Sebagai contoh, kajian pada tahun 2005 mengenai sumber-sumber pencemaran air di hulu Sungai Citarum ${ }^{3}$ menemukan bahwa pencemaran sebagian besar disebabkan oleh aktivitas industri di bagianbagian hulu sungai. Pada saat itu lebih dari 800 pabrik tekstil beroperasi di kawasan Majalaya dan sekitarnya, sebelah selatan Bandung ${ }^{4}$. Namun tidak dapat dipungkiri bahwa pencemaran Sungai Citarum sudah berawal di bagian atas, di dekat hulunya, sektor pertanian juga berkontribusi terutama dalam penggunaan pestisida-pestisida yang persisten dan berbahaya seperti DDT (dichloro-diphenyltrichloroethane) yang di Indonesia telah dilarang penggunaannya beberapa tahun yang lalu ${ }^{5}$ dan lindane $^{6}$. Bukti pencemaran bahan kimia berbahaya mungkin tidak terlalu kasat mata, tetapi dapat menimbulkan ancaman serius jangka panjang baik bagi lingkungan maupun kesehatan manusia.

Sungai Citarum memiliki peran penting dalam pembangunan ekonomi, tidak hanya bagi masyarakat yang tinggal di sekitarnya tetapi juga bagi mereka yang tinggal ratusan kilometer nan jauhnya. Sungai Citarum merupakan sumber pasokan air minum bagi penduduk Jawa Barat dan ibukota Jakarta. Daerah aliran Sungai Citarum didominasi oleh sektor industri manufaktur seperti tekstil, kimia, kertas, kulit, logam/elektroplating, farmasi, produk makanan dan minuman, dan lainnya. Badan Pengelolaan Lingkungan Hidup Daerah Jawa Barat (BPLHD Jabar) telah mengkonfirmasi bahwa limbah industri jauh lebih intens dalam hal konsentrasi dan mengandung bahan-bahan berbahaya. Sebanyak 48\% industri yang diamati, rata-rata pembuangan limbahnya 10 kali melampaui baku mutu yang telah ditetapkan. ${ }^{7}$

3 Parikesit, Salim H, Triharyanto E, Gunawan B, Sunardi, Abdoellah OS \& Ohtsuka R (2005). Multi-Source Water Pollution in the Upper Citarum Watershed, Indonesia, with Special Reference to its Spatiotemporal Variation. Environmental Sciences 123 (2005), 121-131, MYU Tokyo. http://122.249.91.209/myukk/free_journal/Download.php?fn=ES587_full.pdf

4 Ibid.

5 Indonesia. Peraturan Pemerintah Republik Indonesia Nomor 74 Tahun 2001 Tentang Pengelolaan Bahan Berbahaya Dan Beracun

6 Parikesit et al (2005) op cit.

7 BPLHD Provinsi Jawa Barat. Status Lingkungan Hidup Daerah 2010. 
Kontaminasi bahan-bahan kimia berbahaya dan beracun industri dibuktikan oleh sejumlah penelitian. Perhatian utama diberikan pada bahan kimia beracun yang ditemukan di sungai, yaitu logam berat. Logam berat merupakan elemen yang tidak dapat terurai (persisten) dan dapat terakumulasi melalui rantai makanan (bioakumulasi), dengan efek jangka panjang yang merugikan pada makhluk hidup ${ }^{8}$. Sebuah investigasi mengenai bioakumulasi mengungkapkan bahwa logam berat seperti Kadmium (Cd), Tembaga (Cu), Nikel (Ni), dan Timbal (Pb) ditemukan dalam kadar yang tinggi pada dua spesies ikan yang biasa dimakan, Oreochromis nilotica dan Hampala macrolepidota ${ }^{9}$.

\section{Berbagai produk : Dibuat di Indonesia untuk Dunia}

Beberapa waktu belakangan terjadi peningkatan jumlah ekspor barang yang mempunyai nilai tambah seperti jaket, celana panjang, gaun, dan busana resmi, baik untuk pria maupun wanita dibanding dengan bahan-bahan dasar. ${ }^{10}$ Banyak merk busana terkemuka dunia menggunakan Indonesia sebagai lokasi manufaktur untuk menopang ekspor global mereka dan sekitar 61 persen garmen diekspor ke pasar international.

Di Indonesia, tidak kurang dari 80 persen dari total industri manufaktur terkonsentrasi di Pulau Jawa, seperti Bandung yang merupakan kawasan dengan keberadaan pabrik manufaktur terbanyak (37 persen) dari total industri manufaktur di Jawa Barat pada tahun $2007^{11}$, disamping itu Propinsi Jawa Barat juga merupakan pusat tekstil modern dan industri busana di Indonesia. Kebanyakan

8 Terangna. 1991. Water Polution. The Course of The Environmental Impact Assessment. Instituteof Ecology. Padjajaran University

9 Greenpeace Asia Tenggara, Walhi Jawa Barat (2012), Bahan Beracun Lepas Kendali, Sebuah Potret Pencemaran Bahan Kimia Berbahaya dan Beracun di Badan Sungai Serta Beberapa Titik Pembuangan Industri Tak Bertuan, Studi Kasus Sungai Citarum.http://www. greenpeace.org/seasia/id/PageFiles/469211/Full\%20report $\% 20$ Bahan $\% 20$ Beracun $\% 20$ Lepas\%20Kendali.pdf

10 Global Business Guide Indonesia (2013). Manufacturing Indonesia's Garment and Apparel Sectorhttp://www.gbgindonesia.com/en/manufacturing/article/2012/indonesia_s garment and apparel sector.php

11 Wahyudi ST \& Mohd Dan Jantan MD (2010). Regional Patterns of Manufacturing Industries: a Study of Manufacturing Industries in Java Region, Indonesia, Philippine Journal of Development Number 68, First Semester 2010, Volume XXXVII, No. 1, p.96 http://www3. pids.gov.ph/ris/pjd/pidspjd10-1indonesia.pdf 
industri beroperasi di sepanjang daerah aliran sungai (DAS) Citarum. Banyaknya berdiri pabrik-pabrik manufaktur di daerah ini tidak terlepas dari ketersediaan lahan yang cukup, infrastruktur yang memadai, sumberdaya alam, dan kedekatan jarak dengan Jakarta atau pusat bisnis.

Sekitar 60 persen dari total produsen atau perusahaan tekstil nasional berada di Jawa Barat atau di sepanjang DAS Citarum. ${ }^{12}$ Pabrik tekstil di Sungai Citarum juga paling mendominasi dibanding sektor lainnya, mewakili 46 persen dari keseluruhan industri ${ }^{13}$. Penggunaan bahan kimia berbahaya dalam industri tekstil khususnya dalam kegiatan pewarnaan tidak dapat "terhindari". Industri lebih memilih menggunakan pewarna berbahan kimia karena mudah didapatkan dalam jumlah banyak di pasaran. Sementara pewarna alami dari tumbuhan membutuhkan proses panjang dan rumit dalam mengekstraknya. Pewarna kimia sintetis secara besar-besaran yang dikombinasikan dengan penggunaan bahan kimia lainnya digunakan untuk mengantikan pewarna alami, dimana di antara bahan-bahan yang digunakan tersebut mengandung bahan berbahaya beracun(B3) di antaranya nonylphenol (NP) dan tributyl phosphate (TBP). Penggunaan bahanbahan kimia secara besar-besaran dalam proses produksi berbanding lurus dalam terhadap limbah yang dihasilkan. Industri akan melakukan pengelolaan terhadap limbah buangan tersebut namun dari beberapa penelitian yang dilakukan oleh banyak pihak di Sungai Citarum menemukan berbagai kandungan bahan kimia yang digunakan oleh industri tekstil di Sungai Citarum turut berkontribusi pada rusaknya Sungai Citarum ${ }^{14}$.

Sektor pewarnaan tekstil memiliki sejarah panjang di sepanjang aliran Sungai Citarum. Nama Citarum berasal dari nama Tarum, tanaman ini dulunya tumbuh di sepanjang Sungai Citarum. Dahulunya, tumbuhan ini digunakan sebagai pewarna alami yang digunakan oleh para pembuat batik. Tanaman ini tidak serta merta dapat langsung dijadikan sebagai pewarna, namun harus diekstrak terlebih dahulu

12 Balai Besar Wilayah Sungai Citarum (2011). Citarum River Basin Status Map. http:// www.citarum.org/upload/knowledge/document/Citarum_Basin_Status_Map_2011.pdf, diakses pada tanggal 25/2/2013

13 Greenpeace Asia Tenggara, Walhi Jawa Barat (2012)op cit.

14 Pencemaran Sungai Citarum Akibat Industri Manufaktur, Uploaded by Muhammad Habibi.https://www.academia.edu/7606825/PENCEMARAN_SUNGAI_CITARUM_ AKIBAT_INDUSTRI_MANUFAKTUR 
dan memang membutuhkan waktu yang panjang dan sedikit sulit. Penggunaan pewarna dari tanaman ini merupakan bagian dari budaya masyarakat di sekitar Citarum. Namun, seiring dengan berjalannya waktu upaya penyelamatan atau pengembangbiakan tanaman tidak dilakukan, dan kini tanaman Tarum tidak lagi dapat ditemukan atau tumbuh di sepanjang aliran Sungai Citarum. Kondisi ini yang kemudian menjadi salah satu pemicu bagi pembuat batik beralih menggunakan pewarna sintetis. ${ }^{15}$

Greenpeace International pernah melakukan investigasi dan mengungkap hubungan bisnis atau setidak-tidaknya berhubungan dengan bagian dari PT.Gistex Group perusahan yang terasosiasi dengan pabrik yang melakukan pencemaran (Divisi Tekstil PT. Gistex) di Indonesia dengan beberapa merk-merk fashion global. Di antaranya adalah GAP Inc (yang memiliki merk Gap, Old Navy dan Banana Republic), Marubeni Corporation, Brook Brother, Adidas Group dan H\&M. Namun Adidas Group dan H\&M sedikit lebih maju dibanding yang lainnya dimana kedua perusahaan ini telah membuka informasi kepada publik terkait dengan rantai produksi global mereka, ${ }^{16}$ dan termasuk membuat data pencemaran yang mudah diakses (melalui pemasok mereka) oleh publik secara online, seperti skema IPE ${ }^{17}$.

Keterbukaan informasi memiliki peranan penting dalam mengatasi pencemaran bahan-bahan kimia berbahaya dari industri tekstil. Keterbukaan informasi ini juga akan menjembatani kepentingan industri dengan berbagai merk dalam komitmen perlindungan terhadap lingkungan. Hubungan yang erat dan kuat antara pemasok dan merk-merk (Supply Chain) tentu akan membantu terwujudnya sumber air yang aman dan bersih, termasuk dengan merk-merk yang terhubung dengan industri tekstil yang beroperasi di sepanjang Sungai Citarum. Selanjutnya konsumen juga berhak tahu mengenai praktik-praktik produksi yang dilakukan oleh produsen, jenis dan bahan kimia yang digunakan dalam kegiatan produksi termasuk sistem pengelolaan limbah serta pembuangan limbah ke badan air setelah melalui tahapan pengelolaan.

15 Wahyudi ST \& Mohd Dan Jantan MD (2010), op cit.

16 Greenpeace International, Toxit Threads: Meracuni Surga, dipublis pada bulan April 2013

17 IPE, or the Institute of Public\& Environmental Affairs, is anenvironmental NGO in China:http://www.ipe.org.cn/en/pollution/index.aspx 
Keindahanmotif, warna dan modeldaripakaianadalah pemikatbagikonsumen untuk membeli dan memiliki dari berbagai model yang ditawarkan tersebut. Jika tidak selektif dalam memilih dan mencari tahu mengenai proses produksinya dapat dipastikan bahwa konsumen juga berkontribusi terhadap pencemaran yang dilakukan oleh produsen dengan asumsi bahwa belum seluruhnya industriindustri tekstil "ramah" terhadap lingkungan atau berkomitmen terhadap nol buangan limbah bahan berbahaya dan beracun dalam produksinya.

Indahnya fashion tidak mesti harus mengorbankan lingkungan. Konsumen bisa menggunakan pengaruh atau memainkan peran dalam mewujudkan masa depan bebas limbah. Terutama terhadap merk-merk yang menjadi idola di pasaran. Partisipasi publik dalam mendorong produsen untuk membersihkan rantai produk mereka dari bahan berbahaya dan beracun sekaligus memastikan tidak ada lagi bahan kimia berbahaya dalam pakaian yang kita gunakan. Dorongan itu bisa saja datang lebih luas dari kalangan aktifis, perancang busana, pengamat, blogger dan para pecinta busana. Konsumen adalah raja, pepatah ini diakui oleh kalangan produsen dimana tidak dapat dipungkiri konsumen dapat memberikan pengaruh dalam memainkan perananannya masing-masing.

\section{Membuang Limbah di Sungai Citarum}

Sungai Citarum merupakan sungai terbesar di Jawa Barat. Airnya bersumber dari puncak gunung vulkanik di kawasan pesisir selatan jawa dan mengalir ke arah barat laut sejauh 270 kilometer. Pada 200 kilometer pertama sungai mengalir melalui dataran bergunung-gunung dan berbukit, kemudian melalui tiga bendungan dan pada 70 kilometer berikutnya mengairi tanah dataran yang luas sebelum berakhir di Laut Jawa di sebelah timur Jakarta. ${ }^{18}$ Karakter iklimnya dibagi dalam dua garis besar musim: musim hujan pada November hingga April, dan selebihnya adalah musim kering. Banjir adalah bagian yang biasa, terutama di musim penghujan.

Sungai Citarum memiliki peran penting di kawasan ini sebagai sumber air bagi pertanian, rumah tangga, industri, dan sebagai asimilasi pencemaran. Sungai Citarum juga menyediakan energi bagi tiga bendungan listrik tenaga air, dan

18 Fullazaky MA (2010). Water quality evaluation system to assess the status and the suitability. Environ Monit Assess (2010) 168:669-684. Also see Chapter 3. 
menurut laporan menyumbang hingga 20 persen pendapatan domestik kotor (gross domestic product) Indonesia dari sektor manufaktur serta 80 persen permukaan airnya, melalui kanal Tarum Barat, menyuplai sumber air minum Jakarta. Air dari Sungai Citarum juga digunakan untuk irigasi ratusan ribu hektar lahan persawahan dan lahan pertanian, serta menyuplai kebutuhan air minum bagi kota-kota besar termasuk Bandung dan Jakarta. Hampir 40 juta orang bergantung pada Sungai Citarum $^{19}$, pada tahun 1984, Pemerintah mengidentifikasi Sungai Citarum sebagai "sungai superprioritas" 20 .

Sebuah penelitian terhadap kualitas air sungai pada tahun 2010 menyimpulkan bahwa Sungai Citarum secara umum berada dalam kualitas yang sangat buruk menurut parameter polusi, ${ }^{21}$ kecuali di bagian sungai yang telah melalui Bendungan Jatiluhur (karena telah mendapat efek pemurnian alami dari tiga danau-danau buatan). Penelitian ini juga memperingatkan akan meningkatnya degradasi kualitas air dari tahun ke tahun, akibat meningkatnya pasokan polusi dari limbah industri serta limbah domestik yang tidak dikelola, terutama yang terjadi di kawasan Bandung.

Pertumbuhan industri dan penduduk yang bermukim di tepi sungai menjadikan Sungai Citarum sebagai tempat umum untuk membuang limbah domestik dan limbah-limbah industri, dimana dalam beberapa kasus pembuangan limbah akibat kegiatan industri tanpa melalui proses pengelolan sama sekali bahkan untuk penanganan tingkat dasar sekalipun.22 Pada bulan Mei 2012, Greenpeace Indonesia melakukan sampling air limbah yang dibuang oleh PT.Gistex di tiga titik pembuangan (Outfall). Dari sampel itu terindentifikasi beragam bahan kimia banyak di antaranya yang mengandung unsur berbahaya, ada yang merupakan toksik bagi kehidupan akuatik dan bersifat persisten yaitu akan bertahan dalam waktu lama pada saat dilepaskan ke lingkungan. ${ }^{23}$ Walau demikian, masalah air

19 Press Release, Melwan Lupa Citarum. http://www.sorgemagz.com/press-releasemelawan-lupa-citarum/\#.V1fxCIF97IU

20 Indonesia, Keputusan bersama Menteri Dalam Negeri No.19/1984; Menteri Kehutanan No.059/1984 dan Menteri Pekerjaan Umum No.124/1984, Citarum adalah sungai prioritas super untuk Indonesia.

21 Fullazaky MA (2010) opcit.

22 Greenpeace International, Toxit Threads: Meracuni Surga (2013), op. cit

23 Brigden K, Labunska I, Santillo D \&Wang M (2013). Organic chemicaland heavy metal contaminants in wastewaters discharged from two textilemanufacturing facilities in 
limbah domestik yang tidak dikelola dan secara kasatmata memang keberadaan sampah terlihat parah.Pembedanya bahwa limbah industri lebih terkonsentrasi dan mengandung banyak materi-materi berbahaya. Bukti pencemaran bahan kimia berbahaya mungkin tidak terlalu kasat mata, tetapi dapat menimbulkan ancaman serius jangka panjang baik bagi lingkungan maupun kesehatan manusia.

Kajian pada tahun 2005 mengenai sumber-sumber pencemaran air dibagian hulu Sungai Citarum ${ }^{24}$ menemukan bahwa level pencemaran sebagian besar disebabkan oleh aktivitas industri di bawah hulu sungai. Secara jumlah, limbah industri memang lebih sedikit jika dibandingkan dengan limbah domestik yang beragam jenis dan bentuknya, tetapi berdasarkan kajian pemerintah air limbah industri lebih terkonsentrasidan bersifat persisten dan dapat berada dalam sungai dalam periode waktu lama setelah dibuang serta beberapa diantaranya mampu berakumulasi di dalam tubuh makhluk hidup. ${ }^{25}$ Sementara pada penelitian pada tahun 2009 menemukan konsentrasi logam berat tembaga, timah dan nikel di dalam ikan secara umum meningkat di Sungai Citarum dari hulu ke hilir. ${ }^{26}$ Pencemaran logam berat merupakan masalah serius yang juga harus segera ditangani, salah satunya dengan melakukan identifikasi sumber pencemarannya. Dan tidak tertutup kemungkinan logam berat tersebut berasal dari fasilitas-fasilitas dalam industri tekstil dan berbagai industri lainnya di sepanjang Sungai Citarum. Kajian di atas menunjukkan bahwa persoalan limbah bahan kimia dari sektor industri belum ditangani dengan serius baik dalam bentuk penegakan hukum seperti aspek penaatan melalui standar baku mutu yang ditetapkan oleh regulasi maupun dalam bentuk kegiatan pemantauan berkala atau monitoring ilmiah.

Indonesia.http://www.greenpeace.org/international/en/publications/Campaignreports/Toxics-reports/Polluting-Paradise

24 Parikesit et al (2005) op cit.

25 BPLHD Provinsi Jawa Barat. Status Lingkungan Hidup Daerah 2010, op.cit

26 Roosmini D, Hadisantosa F, Salami IRS, Rachmawati S, (2009), Heavymetals level in Hypocarcus Pargalis as biomarker in upstream Citarum River,West Java, Indonesia, p31-36, in South East Asian Water Environment,2009 IWA Publishing. http://books.google.co.uk/ books/about/Southeast_Asian_Water_Environment_3.html?id=6pahUcse7TcC 


\section{Mengungkap Bahan Kimia di Citarum}

Pada tahun 2012, sebuah investigasi dilakukan oleh Greenpeace Asia Tenggara bersama WALHI Jawa Barat, dibantu oleh Institute of Ecology, Universitas Padjadjaran dan Lab. Afiliasi Kimia, Univesitas Indonesia, menelusuri dampak polusi industri terhadap Sungai Citarum. Riset ini mengukur buangan limbah dan kualitas air sungai di 10 lokasi, mulai dari sumber mata air yang asri, hingga hilir sungai. ${ }^{27}$ Beberapa titik pembuangan limbah tak bertuan atau yang lazim dikenal dengan sebutan "pipa siluman" bersama dengan air sungai dan sedimennya dijadikan sampel. Sampel yang diuji adalah kandungan logam berat seperti Timbal $(\mathrm{Pb})$, Merkuri (Hg), Mangan (Mn), Ferrum (Fe), Krom (Cr), Seng (Zn), Cadmium (Cd) dan lain-lain serta berbagai parameter polusi air pada umumnyadiantaranya Biochemical oxygen demand (BOD), Chemical oxygen demand (COD), Total suspended solids (TSS), Amonia Total $\left(\mathrm{NH}_{3}-\mathrm{N}\right)$, Sulfida dan Keasaman $(\mathrm{pH})$ dan bahan kimia organik berbahaya. Hasilnya menunjukkan keberadaan bahan kimia dalam sampel limbah cair, termasuk logam berat seperti Merkuri, Kromium Heksavalen, Timbal dan Cadmium. Sedimen sungai juga dianalisis dan hasilnya menunjukkan kandungan Kromium, Tembaga dan Timbal yang cukup tinggi pada titik-titik sampling tertentu. ${ }^{28}$ Berbagai bahan kimia organik berbahaya juga terdeteksi di sampelsampel limbah cair, di antaranya: Phthalates, termasuk DEHP, DiBP, DBP dan DEP, ${ }^{29}$ yang terdeteksi pada lima dari tujuh sampel limbah cair, serta BHT. ${ }^{30}$ Penelitian ini mengingatkan kita betapa seriusnya masalah yang dihadapi Sungai Citarum. Harus segera dilakukan evaluasi apakah regulasi saat ini cukup memadai dalam mengatur persoalan limbah kimia yang jenisnya setiap waktu terus bertambah. Begitu pula dengan dorongan dalam melakukan melakukan tindakan penegakan hukum atas pencemaran yang terjadi.

Kandungan logam berat akan memberikan dampak signifikan terhadap lingkungan dan kesehatan manusia. Misalkan saja Timbal $(\mathrm{Pb})$ dapat menghambat pembentukan homoglobin (sebabkan anemia), kerusakan sistem syaraf dan

27 Greenpeace Asia Tenggara, Walhi Jawa Barat (2012)op cit.

28 Ibid.

29 Bis(2-ethylhexyl) phthalate (DEHP), Di-isobutyl phthalate (DiBP), Dibutyl phthalate (DBP), Diethyl phthalate (DEP)

30 2,6-bis (dimethyl ethyl-4 methyl) phenol, also known as butylated hydroxyltoluene (BHT) 
bersifat karsinogenik. Paparan Mangan (Mn) melalui jalur kulit mengakibatkan tremor, gangguan koordinasi dan tumor. Merkuri $(\mathrm{Hg})$ bersifat racun dan akan terakumulasi dalam ginjal, otak, hati dan janin. DiBP (Di-isobutyl phthalate) menganggu kerja kelenjar endoktrin dan bersifat racun bagi kehidupan akuatik. ${ }^{31}$ Dan banyak kandungan lainnya yang memberikan dampak serius bagi kesehatan.

\section{Investigasi Terhadap Perusahaan Tekstil}

Tekstil dan pakaian merupakan bagian penting dari ekonomi Bandung. Industri tekstil telah memberikan sumbangan terhadap bagi pendapatan daerah serta banyak menyerap tenaga kerja dan juga memberikan multiplier effect/ bagi usaha lainnya.

PT. Gistex adalah salah satu perusahaan manufaktur tekstil polyester yang terletak di dekat Desa Lagadar Margaasih atau di sebelah barat Kota Bandung. Lokasi berada tepat di pinggir Sungai Citarum. Perusahaan ini didirikan pada tahun 1975 hingga sampai tahun 2007, perusahaan ini telah memiliki delapan pabrik dengan jumlah karyawan sekitar 3.000 orang dan memproduksi 12 juta potong pakaian per tahun dan 6 juta yard (5,5 juta meter) bahan pakaian per bulan ${ }^{32}$. PT. Gistex merupakan salah satu perusahaan manufaktur (pembuatan) terbesar di Bandung, dengan fokus pada tekstil dan busana. Produk-produknya juga diekspor ke berbagai penjuru dunia. Di Indonesia, PT. Gistex memiliki enam lokasi fasilitas dengan kantor pusat Divisi Tekstil dan Garmen berlokasi di Bandung.

Fasilitas Pabrik PT. Gistex berbatasan dengan perumahan penduduk dan peternakan, Sungai Citarum ada di selatan pabrik. Limbah dari proses tekstil dilaporkan telah ditangani dengan instalasi pengolahan air limbah (IPAL), sebelum akhirnya dialirkan ke sungai melalui pipa pembuangan (outfall) utama (khususnya pada jam-jam operasi). Terdapat dua titik pembuangan (outfall) selain pipa pembuangan utama yang sesekali digunakan untuk membuang air limbah meski secara kasat mata tidak jelas dari titik mana dari dalam pabrik air limbah

31 Widowati, Dr. Ir., Msi, Astiana Sastiono, Dr. Ir. MSc \& Raymond Jusuf R, Dr. Msi. 2008. Efek Toksik Logam: pencegahan dan penanggulangan pencemaran. Penerbit Andi Yograkarta. $h$. 409

32 Gistex, Indonesia Integrated Textile Industry, 32 Years Anniversary,1975 - 2007 
itu keluar. Beragam bahan kimia teridentifikasi dalam sampel limbah cair yang dilakukan oleh Greenpeace di salah satu perusahaan yang limbahnya berujung pada Sungai Citarum. Empat sampel air limbah dikumpulkan pada dua hari yang berbeda dari outfall fasilitas PT.Gistex. Semua sampel dianalisa di laboratorium riset Greenpeace(Universitas Exeter, Inggris) dan hasilnya menyimpulkan banyak bahan kimia yang dikenal memiliki sifat berbahaya, termasuk bersifat toksik terhadap akuatik, persisten (sulit terurai) dan dapat terakumulasi pada tubuh makhluk hidup. ${ }^{33}$

Bahan kimia yang ditemukan di outfall utama, di antaranya; nonylphenol $(N P)$, kontaminan lingkungan yang sudah terkenal bersifat persisten dengan sifat menganggu kerja hormon, serta ditemukan nonylphenol ethoxylates (NPEs), yang digunakan sebagai deterjen dan surfaktan pada produksi dan pencucian tekstil, dimana NPEs kemudian akan terurai menjadi NP.Tributyl phosphate (TBP), sebuah materi kimia berbahaya yang digunakan pada industri tekstil sebagai carrier untuk cat tertentu, sebagai plasticiser dan antifoaming agent, dimana materi ini bersifat beracun bagi kehidupan akuatik dan persiten taraf sedang. Terdapat antimony terlarut dalam konsentrasi yang tinggi, sebuah metaloid toksik yang digunakan dalam produksi polyster. Sementara di outfall lainnya ditemukan bahwa air limbah yang dikeluarkan dari salah satu outfall lainnya yang lebih kecil bersifat sangat basa ( $\mathrm{pH} 14)$, membahayakan perairan dan organisme yang berkontak dengannya. Limbah tersebut juga mengandung asam p-terephthalic (bahan baku yang digunakan dalam produksi PET Polyester), hal ini menunjukkan bahwa limbah cair tersebut bahkan belum menerima pengolahan yang paling mendasar sekalipun sebelum dibuang ke badan air. ${ }^{34}$ Secara umum dapat disampaikan bahwa PT. Gistex merupakan contoh nyata akan penggunaan dan pembuangan bahan kimia berbahaya dari produsen tekstil Indonesia. Praktik ini dapat menjadi ilustrasi terhadap persoalan pembuangan limbah kimia ke sungai di sektor industri tekstil dan garmen.

\section{Nonylphenol (NP) dan Nonylphenolethoxylates (NPEs)}

Salah satu kegunaan Nonylphenol (NP) adalah untuk produksi berbagai Nonylphenolethoxylates (NPEs). Setelah digunakan NPEs akan terurai kembali

33 Greenpeace International, Toxit Threads: Meracuni Surga (2013), op cit.

34 Ibid. 
menjadi NP. NP dikenal dengan sifatnya yang persisten, bioakumulatif dan toksik, termasuk risikonya menganggu kerja hormon. NPEs adalah kelompok bahan kimia buatan manusia. Bahan ini digunakan sebagai deterjen dan surfaktan dan termasuk dalam berbagai formulasi bahan yang digunakan produsen tekstil. Penggunaan NP dan NPEs dalam industri tekstil dan pembuangan limbahnya belum diatur dalam regulasi di Indonesia, namun di Negara lain jenis bahan ini sudah lama diatur dan dibatasi penggunaannya. ${ }^{35}$

\section{Meningkatkan Kontrol Dalam Upaya Pencegahan}

Saat ini regulasi yang tersedia dalam mengatasi pencemaran air di Indonesia masih mengandalkan model pendekatan atur dan awasi (command and control). Dalam hal ini Pemerintah bertugas menetapkan baku mutu dan persyaratan yang harus dipatuhi oleh pelaku usaha. Di antaranya menetapkan kelas air seperti kelas I, II, III dan IV yang dinilai masih layak untuk dimanfaatkan bagi peruntukan tertentu termasuk penetapan baku mutu air guna mengatur level maksimum polutan dengan parameter tertentu. Merujuk pada Peraturan Pemerintah Nomor 82 Tahun 2001 Tentang Pengelolaan Kualitas Air dan Pengendalian Pencemaran Air Pasal 8 ayat (1) menyebutkan bahwa; a) Kelas satu, air yang peruntukannya dapat digunakan untuk air baku air minum, dan atau peruntukan lain yang mempersyaratkan mutu air yang sama dengan kegunaan tersebut; b) Kelas dua, air yang peruntukannya dapat digunakan untuk prasarana/sarana rekreasi air, pembudidayaan ikan air tawar, peternakan, air untuk mengairi pertanaman, dan atau peruntukan lain yang mempersyaratkan mutu air yang sama dengan kegunaan tersebut; c) Kelas tiga, air yang peruntukannya dapat digunakan untuk pembudidayaan ikan air tawar, peternakan, air untuk mengairi pertanaman, dan atau peruntukan lain yang mempersyaratkan mutu air yang sama dengan kegunaan tersebut; d) Kelas empat, air yang peruntukannya dapat digunakan untuk mengairi pertanaman dan atau peruntukan lain yang mempersyaratkan mutu air yang sama dengan kegunaan tersebut ${ }^{36}$.

35 Ibid.

36 Indonesia, Peraturan Pemerintah Nomor 82 Tahun 2001 Tentang Pengelolaan Kualitas Air dan Pengendalian Pencemaran Air 
Sementara ketentuan mengenai baku mutu limbah diatur dalam Peraturan Menteri Lingkungan Hidup Nomor 5 Tahun 2014 Tentang Baku Mutu Air Limbah. Terdapat 42 jenis tipe industri yang diatur mengenai baku mutu air limbahnya. ${ }^{37}$ Di luar parameter umum seperti Biochemical oxygen demand (BOD), Chemical oxygen demand (COD), Total suspended solids (TSS), standard yang ditetapkan untuk industri tekstil hanya berupa Kromium, Fenol, Ammoniadan Sulfida, untuk berbagai tipe proses tekstil. Pengaturan ini dipandang terdapat kelemahan-kelemahan, yaitu tetap mengizinkan kandungan bahan berbahaya beracun walau sampai batas tertentu tanpa memperhatikan perkembangan dalam penggunaan bahan kimia tersebut di industri tekstil

Guna memenuhi aturan baku mutu, pelaku usaha mengandalkan instalasi pengolahan akhir limbah (IPAL) atau lebih populer disebut dengan istilah endof-pipe dalam mengelola buangan limbahnya. Terlepas dari masalah kurangnya kemampuan Pemerintah dalam mendeteksi dan menindak pelanggaran yang kerap terjadi terutama dalam hal buangan limbah secara ilegal, namun terdapat masalah mendasar yang tidak dapat ditangani oleh sistem IPAL. Sistem pengelohan limbah akhir yang kita kenal saat ini dengan prinsip kerja menguraikan, memisahkan dan mengencerkan kontaminan sebelum limbah dilepaskan ke lingkungan. Artinya sistem ini diasumsikan bahwa semua polutan dapat terurai, pada kenyataannya tidak semua polutan dapat diuraikan.

Pengaturan seperti ini sepertinya menyimpulkan semua persoalan polutan tersebut akan selesai dengan cara diuraikan, dipisahkan dan diencerkan. Di atas telah dijelaskan bahwa tidak semua polutan dapat diatasi dengan sistem seperti itu. Efektifitas penggunaan model ini sebagai langkah dalam upaya kontrol dan pencegahan masih diragukan. Maka perlu pengetatandalam pemberian izin serta pembatasan pengunaan kandungan bahan berbahaya dan beracun dalam produksi tekstil terutama terhadap jenis-jenis dari bahan tersebut dengan memperhatikan perkembangan dari sifat bahan kimianya, bisa diuraikan atau tidak, disinilah kuncinya. Singkatnya yang diatur adalah bahannya karena tidak semua polutan dapat diuraikan dalam sistem end-of-pipe.

37 Indonesia, Peraturan Menteri Lingkungan Hidup Nomor 5 Tahun 2014 Tentang Baku Mutu Limbah 
Bersandar pada sistem pengolahan limbah akhir merupakan pemecahan masalah yang bersifat reaktif karena limbah terlanjur tercipta. Kegiatan pengolahan limbah hanya mengubah bentuk limbah, memindahkan dari satu media ke media lain, terutama terhadap materi limbah yang persisten atau tidak dapat diurai. Untuk itu sebaiknya adalah memastikan tidak ada materi persisten khususnya dari bahan berbahaya beracun yang digunakan sejak awal produksi sampai proses akhir. Serta menekankan prinsip kehati-hatian atas sebuah tindakan yang memungkinkan terjadinya kerusakan pada lingkungan. Mencegah adalah pilihan yang lebih baik dan aman, untuk itu rancangan produk juga harus mulai beralih dari ketergantungan dalam penggunaan bahan kimia berbahaya.

Bagian berikutnya peranan kontrol juga bisa maksimal dilakukan jika terdapat ketersediaan informasi yang cukup dari sebuah kegiatan industri. Indonesia sendiri telah memberikan jaminan hukum bagi setiap orang atau individu guna memperoleh akses informasi terutama dalam pemenuhan hak masyarakat atas lingkungan. Artinya, sudah barang tentu bahwa semua perusahaan wajib memberikan informasi yang benar mengenai pelaksanaan-pelaksanaan kewajibankewajiban pengelolaan kualitas air dan pengendalian polutan guna menegakkan ketaatan hukum. Namun memang informasi mengenai pelaksanaan kewajiban pelaku usaha atau industri jarang ditemukan, kalaupun ada kebanyakan informasi yang berkaitan tidak dipublikasi. Keterlibatan publik sebagai bagian dari pengawasan publik sulit melakukan peranannya dalam memberikan masukan, pendapat dan saran ataupun menyampaikan keberatan atas kegiatan industri yang tidak melakukan kewajiban dalam mewujudkan kelestarian lingkungan atau diduga melanggar aturan yang berlaku.

Tidak heran bahwa tingkat kesadaran, partisipasi dan ketaatan pada hukum oleh industri masih kecil. Beberapa waktu belakangan, Badan Lingkungan Hidup Daerah (BPLHD) Propinsi Jawa Tengah memberikan sanksi terhadap 29 perusahaan garmen dan tekstil karena melanggar peraturan terkait kelestarian lingkungan dan pembuangan limbah industri yang berujung pada pencemaran lingkungan. ${ }^{38}$ Sementara di Jawa Barat, 14 perusahaan dari berbagai sektor industri, termasuk pembuatan garmen menerima sanksi administratif dan kriminal karena

38 http://www.suntexasia.com/details/newsid/2950/ttl/29_industry_garment_and_ textile_in_central_java_pollute_the_environment.html 
mencemari Sungai Citarum dengan limbah berbahaya. Hanya saja pemerintah mencatat bahwa masih ada kasus-kasus serupa di Sungai Citarum. ${ }^{39}$ Kondisi ini menggambarkan bahwa kurangnya pengawasan terhadap praktik-praktik pembuangan limbah industri ke media lingkungan salah satunya sungai, maka jika keadaan ini dibiarkan tanpa pengetatan pengawasan, perbaikan dan penggunaan bahan berbahaya beracun di berbagai sektor, maka pencemaran akan terus terjadi.

Undang-undang Nomor 32 Tahun 2009 Tentang Perlindungan dan Pengelolaan Lingkungan Hidup pada bagian pencegahan ${ }^{40}$ telah mengatur tentang instrumen kebijakan dalam rangka mencegah pencemaran sejak dari awal pelaksanaan usaha atau kegiatan diataranya melalui kajian analisis mengenai dampak lingkungan (Amdal) yang akan mengidentifikasi seluruh persoalan yang akan berdampak di kemudian hari dan upaya pemantauan serta pengelolaannya. Amdal menjadi salah satu persyaratan utama dalam memperoleh izin lingkungan dan bagian dari upaya preventif dalam rangka pengendalian dampak lingkungan sebagai rujukan dalam melakukan pengawasan.Tapi tentunya tindakan represif juga harus segera dilakukan dalam hal kerusakan sudah terjadi maka harus ada penegakan hukum yang efektif terhadap pelaku pengrusakan atau pencemaran tersebut. Intinya penekanan pertanggungjawaban mutlak terhadap usaha atau kegiatan yang berdampak pada lingkungan.

Menyadari berbagai dampak negatif yang dapat ditimbulkan dari sebuah usaha atau kegiatan mengharuskan mengedepankan pendekatan pencegahan secara dini. Disamping menggunakan semua instrumen lingkungan yang harus dipenuhi, keterlibatan publik sebagai wujud dari partisipasi sosial juga harus ditekankansalah satunya dengan cara menyediakan informasi yang cukup atas sebuah usaha atau kegiatan termasuk informasi input dan output pada setiap tahapan produksi. Tegasnya mencegah dari sumber bahan produksi.

39 http://kabar24.bisnis.com/read/20121218/78/110498/pencemaran-lingkungan-14perusahaan-pencemar-citarum-jabar-kena-sanksi

40 Indonesia, Undang-undang Nomor 32 Tahun 2009 Tentang Perlindungan dan Pengelolaan Lingkungan Hidup 


\section{Penutup}

Sungai Citarum memiliki reputasi buruk sebagai sungai terkotor di dunia. Beragam aktivitas industri yang berada disepanjang aliran Sungai Citarum patut diduga menjadi penyumbang atas kerusakan yang terjadi, dan tak bisa dipungkiri juga bahwa aktifitas domestik turut serta memberikan kontribusinya. Di atas telah diuraikan bagaimana kontribusi industri tekstil terhadap kerusakan yang ada, terlebih pada penggunaan bahan berbahaya dan beracun dan bahan kimia lainnya, dimana diantara bahan-bahan kimia yang digunakan dalam industri tekstil belum diatur secara khusus dalam regulasi yang ada. Sehingga sulit untuk mengeliminiasi penggunaan bahan tersebut serta pembuangannya. Pendekatan pencegahan dalam penggunaan bahan kimia berbahaya dibutuhkan atau sekurang-kurangnya mengedepankan prinsip kehati-hatian sebagai upaya yang harus dipertimbangkan sejak awal.

Penghentian pembuangan bahan kimia berbahaya oleh pabrik tekstil termasuk di seluruh sektor industri membutuhkan komitmen dari produsen dan kemauan politik dalam menuju nol pembuangan semua bahan berbahaya dan beracun. Apa yang terjadi atas pencemaran Sungai Citarum saat ini menjadi bahan evaluasi yang mendalam atas berporasinya ratusan industri terkstil dan industri lainnya di sepanjang sungai. Mendesak untuk dilakukan penyusunan sebuah daftar bahan berbahaya dan beracun agar memudahkan dalam melakukan penataan dalam penggunaan maupun pengawasan yang kemudian didukung oleh sistem registrasi data penggunaan dan pembuangan limbah berbahaya dan beracun dan harus menjadi prioritas untuk ditindaklanjuti segera.Tentu juga harus dibuatkan daftar-daftar bahan kimia yang dibatasi, dikurangi atau tidak boleh sama sekali atau dieliminasi dari penggunaannya. Terakhir adalah melakukan pengawasan yang ketat atas keberadaan bahan kimia berbahaya yang terdapat di pasaran atau yang diperdagangkan secara bebas.

Walaupun saat ini telah tersedia kebijakan perizinan mengenai pembuangan limbah bahan berbahaya dan beracun, namun tetap harus dibatasi khususnya mengenai jenis limbah dari bahan berbahaya dan beracun itu sendiri.Keterbukaan informasi mengenai daftar pengunaan dan pembuangan atau transfer limbah menjadi penting, agar publik sebagai wujud partisipasi sosial dapat melakukan 
pengawasan di lapangan. Pemerintah juga dapat lebih aktif terutama dalam mengontrol peredaran bahan kimia berbahaya yang dijual bebas di pasaran. Terakhir, aspek penegakan hukum memiliki peranan penting dalam memastikan sebuah kebijakan dijalankan melalui peningkatan kontrol dan penindakan.

Konsumen juga harus berperan aktif terutama dalam menggunakan pengaruhnya dalam mendesakindustri-industri dalam mewujudkan masa depan nol pembuangan limbah semua berbahaya dan beracun. Perilaku konsumen juga harus di tata, bahwa semakin tinggi pembelian terhadap produk baru dapat memberikan pengaruh pada pencemaran dalam sistem produksi dibagian hulu. Maka setidak-tidaknya harus mengurangi pembelian produk baru secara berkala. Konsumen juga dapat mendorong komitmen produsen terhadap tanggungjawab terhadap kelestarian lingkungan dan , khususnya pada perusahaan pemilik merkmerk pakaian yang saat ini digemari oleh publik atau menguasai pasar. Tentunya dengan beraksi bersama kita akan mampu mendorong pemerintah untuk lebih mempertahatikan kinerja industri di sektor tekstil. 


\section{DAFTAR PUSTAKA}

Balai Besar Wilayah Sungai Citarum (2011). Citarum River Basin Status Map. http://www.citarum.org/upload/knowledge/document/Citarum_Basin_ Status_Map_2011.pdf, diakses pada tanggal 25/2/2013

Brigden K, Labunska I, Santillo D \&Wang M (2013). Organic chemicaland heavy metal contaminants in wastewaters discharged from two textilemanufacturing facilities in Indonesia.

Business Vibes; Industry Insight (2013). Tekstile Industry in Indonesia, http:// www.busiinessvibes.com/blog/industry-insight-textile-industry-indonesia, export in term of monetary value.

Environment_3.html?id=6pahUcse7TcC

Fullazaky MA (2010). Water quality evaluation system to assess the status and the suitability. Environ Monit Assess (2010) 168:669-684. Also see Chapter 3.

Greenpeace Asia Tenggara, Walhi Jawa Barat (2012), Bahan Beracun Lepas Kendali, Sebuah Potret Pencemaran Bahan Kimia Berbahaya dan Beracun di Badan Sungai Serta Beberapa Titik Pembuangan Industri Tak Bertuan, Studi Kasus Sungai Citarum. http://www.greenpeace.org/seasia/id/PageFiles/469211/ Full\%20report\%20_Bahan\%20Beracun\%20Lepas\%20Kendali.pdf

Greenpeace International, Toxit Threads: Meracuni Surga, dipublis pada bulan April 2013.

http://www.greenpeace.org/international/en/publications/Campaign-reports/ Toxics-reports/Polluting-Paradise

Indonesia, Keputusan bersama Menteri Dalam Negeri No.19/1984; Menteri Kehutanan No.059/1984 dan Menteri Pekerjaan Umum No.124/1984, Citarum adalah sungai prioritas super untuk Indonesia

Indonesia, Peraturan Menteri Lingkungan Hidup Nomor 5 Tahun 2014 Tentang Baku Mutu Limbah 
Indonesia, Peraturan Pemerintah Nomor 82 Tahun 2001 Tentang Pengelolaan Kualitas Air dan Pengendalian Pencemaran Air

Indonesia, Undang-undang Nomor 32 Tahun 2009 Tentang Perlindungan dan Pengelolaan Lingkungan Hidup

Indonesia. Peraturan Pemerintah Republik Indonesia Nomor 74 Tahun 2001 Tentang Pengelolaan Bahan Berbahaya Dan Beracun

IPE, or the Institute of Public\& Environmental Affairs, is anenvironmental NGO in China:http://www.ipe.org.cn/en/pollution/index.aspx

Parikesit, Salim H, Triharyanto E, Gunawan B, Sunardi, Abdoellah OS \& Ohtsuka R (2005). Multi-Source Water Pollution in the Upper Citarum Watershed, Indonesia, withSpecialReferencetoitsSpatiotemporal Variation.Environmental Sciences 123 (2005), 121-131, MYU Tokyo. http://122.249.91.209/myukk/ free_journal/Download.php?fn=ES587_full.pdf

PencemaranSungai Citarum Akibat Industri Manufaktur, Uploaded by Muhammad Habibi. https://www.academia.edu/7606825/PENCEMARAN_SUNGAI CITARUM_AKIBAT_INDUSTRI_MANUFAKTUR

Press Release, Melwan Lupa Citarum. http:/ / www.sorgemagz.com/press-releasemelawan-lupa-citarum/\#.V1fxCJF97IU

Roosmini D, Hadisantosa F, Salami IRS, Rachmawati S, (2009), Heavymetals level in Hypocarcus Pargalis as biomarker in upstream Citarum River,West Java, Indonesia, p31-36, in South East Asian Water Environment,2009 IWA Publishing.http://books.google.co.uk/books/about/Southeast_Asian_ Water_

Wahyudi ST \& Mohd Dan Jantan MD. (2010). Regional Patterns of Manufacturing Industries: a Study of Manufacturing Industries in Java Region, Indonesia, Philippine Journal of Development Number 68, First Semester 2010, Volume XXXVII, No. 1, p.96 